1

Caveat: This is a preprint of a paper of mine appearing in Kant Studien. Do not quote from this preprint, only from the forthcoming version.

\title{
Kant and Whewell on Bridging Principles between Metaphysics and Science
}

\author{
by Steffen Ducheyne, Ghent
}

In this essay, I call attention to Kant's and Whewell's attempt to provide bridging principles between a priori principles and scientific laws. Part of Kant's aim in the Opus postumum (ca. 1796-1803) was precisely to bridge the gap between the metaphysical foundations of natural science (on the Metaphysical Foundations of Natural Science (1786) see section 1) and physics by establishing intermediary concepts or 'Mittelbegriffe'

\footnotetext{
The author currently is Postdoctoral Research Fellow of the Research Foundation (FWO-Vlaanderen) and is associated with the Centre for Logic and Philosophy of Science at Ghent University (Blandijnberg 2, B-9000 Ghent, Belgium, email: Steffen.Ducheyne@UGent.be). The author is indebted to The Master and Fellows of Trinity College Cambridge for their permission to quote from the Whewell Papers and especially to Jonathan Smith, chief-librarian at Wren Library, and his staff for their kind assistance during my research-stay in Cambridge. Finally, the author is thankful to the anonymous referee who suggested several improvements and additions.

The English translations used in this essay are:

- Critique of Pure Reason. In: Critique of Pure Reason. Ed. and transl. by P. Guyer and A. Wood. Cambridge 1998 [1781, 1787].

- Opus postumum. In: Opus postumum. Ed. by E. Förster, translated by E. Föster and M. Rosen. Cambridge 1998 [ca. 1796-1803]. (This translation contains but a selection of OP, AA 21-22; for the selection criteria used, see: xliv-xlv.) - Metaphysical Foundations of Natural Science. In: Metaphysical Foundations of Natural Science. Ed. and transl. by M. Friedman. Cambridge 2004 [1786]. In the references to Kant's work, the page-numbers of these translations are given after their corresponding reference in the Akademie-Ausgabe (e.g. 'MAN, AA 04: 478.15-16; 13'). The original and its translation are separated by a semicolon.
} 
(henceforth this problem is referred to as 'the bridging-problem'). I argue that the late-Kant attempted to show that the concept of 'moving force', an intermediary concept derived from a priori principles, could be given empirical content so that concrete scientific knowledge is arrived at. Thus, the late-Kant wished not only to show that proper scientific laws are necessary a priori (as he had shown in the Metaphysical Foundations of Natural Science) but also that intermediary concepts could be derived from a priori principles which, when interpreted empirically, resulted in the specific forces as established by physics (see section 2).

Of course, William Whewell never knew about Kant's Opus postumum and his attempt to bridge the gap between the metaphysical foundations of science and physics. However, it is striking that Whewell had similar concerns about the Critique of Pure Reason and the Metaphysical Foundations of Natural Science as Kant himself. According to Whewell, the Kantian project was incomplete because it did not show how 'modifications' (in the sense of concretizations) of a priori principles could result in empirical laws (section 3). Next, it will be argued, by taking into account several of Whewell's philosophical notebooks which have scarcely been studied systematically, that Whewell's doctrine of Fundamental Ideas grew out of his dissatisfaction with the Kantian project with respect to the bridging problem and that his own philosophical position should be seen as an attempt to bypass the bridging-problem.

\section{Kant's Metaphysical Foundations of Natural Science}

The publication of the Critique of Pure Reason $(1781,1787)$ is traditionally seen as the apex of Kant's transcendental project - in which he sought to unravel the synthetic a priori concepts of reason ("das synthetische Erkentnis a priori aus Begriffen verstanden" ${ }^{1}$ ). Kant's famous table of transcendental categories, which expounds the necessary conditions of human conceptualisation of all possible experiences, is in Kant's own words "indispensable in the theoretical part of philosophy for

\footnotetext{
${ }^{1}$ OP, AA 21: 60.16-22, cf. 63.12-15, 67.18-23, 69.8-11, 73.11-16, 74.01-03, 75.07-09, 77.04-07, 82.08-24, 85.03-05, 86.18-23, 87.11-15, 89.03-07, 90.22-26, 94.05-09, 99.25-27, 103.04-08, 104.03-07, 107.12-15, 119.13-18, 133.13-15, also: OP, AA 22: 81.03-04, 113.08-11.
} 
completely outlining the plan for the whole of a science insofar as it rests on a priori concepts, and dividing it mathematically in accordance with determinate principles" ${ }^{2}$. In similar spirit, in the preface to his Metaphysical Foundations of Natural Science (published in 1786, i.e. five years after the first edition of the Critique of Pure Reason) in which Kant gave an a priori deduction of "matter in general", he confidently wrote:

In everything that is called metaphysics one can hope for the absolute completeness of the sciences, of such a kind one may expect in no other type of cognition. Therefore, just as in the metaphysics of nature in general, here the completeness of the metaphysics of corporeal nature can confidently be expected. ${ }^{4}$

In the Critique of the Power of Judgment (1790), Kant noted that he had now brought his transcendental project to a close. ${ }^{5}$ His philosophical project prima facie seems to be surrounded by a halo of completeness, certainty and comprehensiveness. However, the late-Kant thought otherwise.

From at least 1796 (and perhaps earlier ${ }^{6}$ ), Kant became aware of the incompleteness of his philosophical system with respect to natural philosophy which he had addressed in his Metaphysical Foundations of Natural Science and, correspondingly, he tried to complete his project by composing the Opus postumum - a work that, according to Kant's own

\footnotetext{
${ }^{2} \mathrm{KrV}$, AA 03: 95.14-23; 214 [bold in translation]. Original: "Denn daß diese Tafel im theoretischen Theile der Philosophie ungemein dienlich, ja unentbehrlich sei, den Plan zum Ganzen einer Wissenschaft, so fern sie auf Begriffen a priori beruht, vollständig zu entwerfen und sie systematisch nach bestimmten Principien abzutheilen [...]".

${ }^{3}$ Friedman (1992), 216.

${ }^{4}$ MAN, AA 04: 473.16-21; 9 [italics in the last sentence added]. Original: "[...] in Allem, was Metaphysik heißt, die absolute Vollständigkeit der Wissenschaften gehofft werden kann, dergleichen man sich in keiner anderen Art von Erkenntnissen versprechen darf, mithin eben so, wie in der Metaphysik der Natur überhaupt, also auch hier die Vollständigkeit der Metaphysik der körperlichen Natur zuversichtlich erwartet werden kann; [...]".

${ }^{5}$ KU, AA 05: 170.21-27.

${ }^{6}$ See Eckart Förster's editorial introduction to the Opus postumum (xvi, xxxvxxxvii). We know for sure that Kant began working on this material in 1796 when he retired from academics.
} 
suggestion, had the running title Transition from the Metaphysical Foundations of Natural Science to Physics. ${ }^{7}$ The reason for Kant's discontent with the Metaphysical Foundations of Natural Science is spelled out in the following section.

Let us first give a general overview what Kant's project was in the Metaphysical Foundations of Natural Science (we shall focus on the relation between metaphysics and natural philosophy). ${ }^{8}$ This technical

\footnotetext{
${ }^{7}$ OP, AA 21: 373.02-03; 10.

${ }^{8}$ The Metaphysical Foundations of Natural Science addresses four issues: phoronomy, i.e. the study of "motion as a pure quantum in accordance with its composition, without any quality of the movable" ("die Bewegung als ein reines Quantum nach seiner Zusammensetzung ohne alle Qualität des Beweglichen”) (first chapter), dynamics, i.e. the study of motion "as belonging to the quality of matter, under the name of an original moving force" ("zur Qualität der Materie gehörig unter dem Namen einer ursprünglich bewegenden Kraft") (second chapter), mechanics, i.e. the study of "matter with this quality as in relation to another through its own inherent force" ("die Materie mit dieser Qualität durch ihre eigene Bewegung gegen einander in Relation") (third chapter), and finally, phenomenology, i.e. the study of motion or rest "in relation to the mode of representation or modality, and thus as appearance of the outer senses" ("auf die Vorstellungsart oder Modalität, mithin als Erscheinung äußerer Sinne") (fourth chapter) (MAN, AA 04: 477.03-13; 12). Note that this division of chapters corresponds to the four categories: quantity, quality, relation and modality, respectively. In the first chapter of this opusculum, Kant considered matter as that which is movable in space and movability as quantity of motion (MAN, AA 04: $480.12-13 ; 15,495.05-10 ; 31)$. When we observe matter in motion we always do so in relative space (absolute space is not an object of experience and refers to "only any other relative space, which I can always think beyond the given space, and which I can only defer to infinity beyond any space" ("nur einen jeden andern relativen Raum, den ich mir außer dem gegebenen jederzeit denken kann, und den ich nur über jeden gegebenen ins Unendliche hinausrücke") (MAN, AA 04: 481.34-35; 16; cf. Friedman (1992), 142-143)). He also showed how quantity of motion of composition of motion can be constructed a priori. In the second chapter, he shows that matter fills space "through the repulsive forces of all its parts" ("durch repulsive Kräfte aller ihrer Theile") (MAN, AA 04: 499.06-09; 36) (he therefore considered such repulsive forces as the primary essential qualities of matter), that attraction is the secondary quality of matter (MAN, AA 04: 499.11-16; 36)), and that matter is indivisible to infinity (MAN, AA 04: 503.21-22; 40). In this chapter he thus treated matter qua quality. In the third chapter, Kant considers the forces of bodies as communicating motion to one another (e.g. by impact) and derives
} 
treatise is essentially a metaphysical study of matter. As Kant puts it, it deals with the "metaphysics of corporeal nature" ("eine abgesonderte Metaphysik der körperlichen Natur der allgemeinen") ${ }^{9}$. This exercise is relevant to general metaphysics since it gives meaning to the pure concepts of understanding and furnishes examples (intuitions) in which the concepts and propositions of metaphysics are realized. ${ }^{10}$

For Kant, natural science meant physics, and physics was, at the time, synonymous to Newtonian mechanics. ${ }^{11}$ The overarching goal was, in line with the Critique of Pure Reason, to elucidate the metaphysics of science that gives proper science (as apposed to improper science which treats its object according to empirical laws only and not according to $a$ priori principles) its apodictic certainty. ${ }^{12}$ In the Metaphysical Foundations, Kant sought to investigate the pure part $^{13}$ of proper natural philosophy, i.e. the metaphysics that natural philosophy presupposes. "Now", Kant noted, "the latter [i.e. the pure part of natural philosophy] must always contain solely principles that are not empirical (for precisely this reason it bears the name of a metaphysics)". ${ }^{14}$ In doing so, Kant meant to offer a "genuine metaphysics of science" ("eine wirkliche Metaphysik der körperlichen Natur"), i.e. a complete analysis of the

\footnotetext{
Newton's laws of motion "from general metaphysics" ("[a]us der allgemeinen Metaphysik”) (MAN, AA 04: 543.22-25; 83; cf. Watkins (2001) - Kant uses metaphysics here (which represents a priori the condition under which alone objects, whose concept must be empirically given, can be further determined $a$ priori) in contrast to transcendental philosophy (which represents a priori the universal conditions under which alone things can be objects of cognition ( $\mathrm{KrV}$, AA 05: 181.15-16)). Here he dealt with matter as having a moving force. In the fourth chapter, he shows that rectilinear, i.e. inertial, motion is a possible predicate, that circular, i.e. orbital motion, is an actual predicate and that in every motion of a body relative to the other an equal and opposite motion of the latter is necessary (MAN, AA 04: 544.32-33; 94). Here he dealt with how motion can be experienced modally.

${ }^{9}$ MAN, AA 04: 478.15-16; 13.

${ }^{10}$ MAN, AA 04: 478.15-19; 13.

${ }^{11}$ See Friedman (2003a).

${ }^{12}$ MAN, AA 04: 468.17-18; 4.

${ }^{13}$ MAN, AA 04: 469.12; 5.

${ }^{14}$ MAN, AA 04: 469.31-33; 5, cf. 482.08-09; 17. Original: "Diese muß nun zwar jederzeit lauter Principien, die nicht empirisch sind, enthalten (denn darum führt sie eben den Namen einer Metaphysik)."
} 
concept of matter "in general" ("überhaupt") which "makes use of no particular experiences, but only that which it finds in isolated (although intrinsically empirical) concept itself, in relation to the pure intuitions in space and time, and in accordance with laws that already essentially attach to the concept of nature in general" ${ }^{\text {"15 }}$. Kant thus isolated metaphysics from physics in the Metaphysical Foundations and it was precisely this separation between both disciplines that would later worry him. Metaphysical knowledge, Kant noted, does not proceed by extending empirical knowledge (e.g. by performing observations and experiments or by applying mathematics to phenomena) but by attaining cognition of what lies beyond the boundaries of experience. ${ }^{16}$ The reason that Kant thought that he had provided a complete metaphysical outline of natural philosophy lies in the fact that he thought that the object of metaphysics is considered in accordance with all necessary laws of thought, which yield a determinate number of cognitions that might be completely exhausted by the table of categories. By contrast, natural science itself has no such determinateness as it involves "an infinite manifold of intuitions (pure or empirical), and thus an infinite manifold of objects of thought" ${ }^{17}$. Correspondingly, Kant concluded that the metaphysical foundations "is useful only for the purpose of guiding natural philosophy, so far as this is ever possible, to explore dynamical grounds of explanation" ${ }^{\prime \prime}$.

\section{Kant's Opus postumum and the hiatus in systemato}

\footnotetext{
15 MAN, AA 04: 472.07-11; 8. Original: "[...] sich keiner besonderen Erfahrungen, sondern nur dessen, was sie im abgesonderten (obzwar an sich empirischen) Begriffe selbst antrifft, in Beziehung auf die reinen Anschauungen im Raume und der Zeit (nach Gesetzen, welche schon dem Begriffe der Natur überhaupt wesentlich anhängen) bedient [...]".

${ }^{16}$ MAN, AA 04: 477.14-35; 13.

${ }^{17}$ MAN, AA 04: 473.26-28; 10. Original: “[...] eine unendliche Mannigfaltigkeit von Anschauungen (reinen oder empirischen), mithin Objecten des Denkens darbieten $[\ldots] "$ ".

${ }^{18}$ MAN, AA 04: 534.26-30; 74. Original: "ist [...] nur zu der Absicht nützlich, [...], so weit als es immer möglich ist, auf die Erforschung der dynamischen Erklärungsgründe zu leiten $[\ldots]$ ".
} 
Left as private notes, the folios composing the Opus postumum ${ }^{19}$ are often redundant and they might prima facie be considered as an unconnected whole. In the Opus postumum, Kant addressed a cornucopia of different topics. ${ }^{20}$ The sections that will occupy us here are the ones in which Kant deals with the transition from the metaphysical foundations of natural philosophy to physics (see infra). Kant began by pointing out that this transition should be a step, not a leap:

\footnotetext{
${ }^{19}$ This posthumous work only recently drew scholarly attention in the English literature. See especially: Caygill (2005), Friedman (1992), Ch. 5, Friedman (2003b), and Förster (2000). See further Mathieu (1989). Some useful and 'older' studies also deserve to be mentioned: Adickes (1920), Hoppe (1969), and Tuschling (1971).

${ }^{20}$ Förster's editorial introduction to the Opus postumum (xxxviii-xliv). For instance, Kant argues that the ether is to be regarded "not just as a hypothetical material, but as a real world-material - given a priori by reason and counting as a principle of the possibility of the experience of the system of moving bodies" ("nicht nur als h y p o the ti s cher S t off um gewisse Erscheinungen erklären zu können sondern als realer und a priori durch die Vernunft gegebener Weltstoff") (OP, AA 21: 216.03-07; 67, cf. 223.10-15; 72, 229.10-12; 76, $550.10-18 ; 80$ ). Kant also discussed the Selbstsetzungslehre according to which self-consciousness is a logical act of thought in which the self makes himself into an object (OP, AA, 22: 413.02-10; 179-180, 119.10-19; 202) (cf. "[t]he first act of the faculty of representation (facultas repraesentativa) is the representation of oneself (apperceptio) through which the subject makes itself into an object (apperceptio simplex)" ("Der erste Act des Vorstellungsvermögens (facultas repraesentativa) ist die Vorstellung seiner selbst (apperceptio) wodurch das Subject sich selbst zum Objecte macht (apprehensio simplex)") (OP, AA 22: $43.07-09 ; 178)$ ). According to Kant, a subject does not only constitute itself as an object but also as a person with moral duties subjected to the categorical imperative - this moral constitution of the self leads to the concept of God (OP, AA 22: 117.01-06; 200-201, 123.21-28-124.01-02; 204-205). Next, Kant also develops transcendental philosophy as philosophy of the self-constitution of reason which inevitably creates the ideas of God, world and moral duty (OP, AA 21: 9-156; 218-256).
} 
8

Progress (progressus) ${ }^{21}$ in knowledge (qua science in general) begins with the collection of the elements of knowledge, then connects them [in the] manner in which they are arranged (systematically). For the division of this enterprise into a doctrine of elements and a doctrine of method constitutes the supreme division; the former presents the concepts, the latter their arrangement in the order to found a scientific whole. The transition (transitus) from one form of knowledge to another must be a step (passus) only, not a leap (saltus); that is, the doctrine of method requires one to pass from the metaphysical foundation of natural science to physics - from concepts of nature given a priori to empirical ones which yield empirical knowledge. The rule herein will be [...] to proceed like elephants, which do not put one of their four feet a step further until they feel that the other three stand firm. $^{22}$

${ }^{21}$ Kant apparently thought that each scientific discipline begins with a systematization followed by an exposition of an adequate theoretical foundation: "If, however, the grounds or principles themselves are still in the end merely empirical, as in chemistry [of which he secretly hoped that it could be soon "physicalized" (Friedman (1992), 287)], for example, and the laws from which the given facts are explained through reason are mere laws of experience, then they carry with them no consciousness of their necessity (they are not apodictally certain), and thus the whole of cognition does not deserve the name of a science in the strict sense; chemistry should therefore be called a systematic art [systematische Kunst] rather than a science." ("Wenn aber diese Gründe oder Principien in ihr, wie z. B. in der Chemie, doch zuletzt blos empirisch sind, und die Gesetze, aus denen die gegebene Facta durch die Vernunft erklärt werden, blos Erfahrungsgesetze sind, so führen sie kein Bewußtsein ihrer Nothwendigkeit bei sich (sind nicht apodiktisch-gewiß), und alsdann verdient das Ganze in strengem Sinne nicht den Namen einer Wissenschaft, und Chemie sollte daher eher systematische Kunst als Wissenschaft heißen.”) (MAN, AA 04: 468.23-29; 4).

${ }^{22}$ OP, AA 21: 386.27-33-387.01-09; 12-13, cf. 407.22-28; 19. Original: "Das Fortschreiten in einer Erkentnis als Wissenschaft überhaupt (progreßus) fängt davon an die Elemente derselben aufzufinden und dann die Art wie sie zusammengeordnet werden sollen (systematisch) zu verknüpfen da dann die Eintheilung dieses Geschäftes in Elementarlehre und Methodenlehre die oberste Eintheilung ausmacht, wovon jene die Begriffe diese die Anordnung derselben um ein Ganzes der Wissenschaft zu begründen vorstellig macht. Der Ubergang (transitus) von einer Art der Erkentnis zu einer andern muß nur ein Schritt (paßus), kein Sprung (saltus) seyn d. i. die Methodenlehre gebietet von den 
The transition from metaphysics to physics cannot lie in the metaphysical foundations of physics, which stipulates only the general nature of the two primitive forces of attraction and repulsion, for "these furnish no specifically determined, empirical properties, and one can imagine no specific [forces] of which one could know whether they exist in nature, or whether their existence be demonstrable",23. Bridging this gap was one of his last philosophical challenges. In a letter to Christian Garve, on 21 September 1798, Kant admitted that this project was a true torment of Tantalus ("ein Tantalischer Schmerz") and that its failure would leave critical philosophy incomplete. ${ }^{24}$

According to the late-Kant, natural philosophy essentially consists of two parts: (i) the metaphysical foundation of physics, which unravels the $a$ priori principles of physics in general, and (ii) proper physics, which deals with the empirical contents of a priori principles (or put differently, which "proceeds from empirical principles" ("von empirischen Principien ausgeht" ${ }^{25}$ ). In other words, in the metaphysical part of natural philosophy we spell out the a priori principles of physics; in the physical part we provide these abstract principles with concrete empirical contents. In this sense, metaphysics provides the form and physics the content or matter of those forms:

The concept of a science of nature (philosophia naturalis) is the systematic representation of the laws of motion ["Gezetze der Bewegung"] of outer objects in space and time, insofar as these [laws] can be known a priori (thus as necessary). ${ }^{26}$ For empirical

metaphysischen Anfangsgründen der Naturwissenschaft zur Physik von Begriffen der Natur die a priori gegeben sind zu empirischen welche ein Erfahrungserkentnis liefern überzus chreiten: wobey dann die Regel seyn wird (nach dem schertzenden Spruch eines Philosophen) es zu machen wie die Elephanten die nicht eher einen der 4 Füße einen Fuß weiter setzen als bis sie fühlen daß die andern drey feststehen."

${ }^{23}$ OP, AA 22: 282.13-17; 100 [italics added]. Original: “[...] die geben gar keine besonders bestimmte von der Erfahrung anzugebende Eigenschaften u. man kann keine specifische ausdenken von denen man wissen könnte ob sie auch in der Natur sind oder auch ob die Existenz von solchen erweislich sey [...]”.

${ }^{24} \mathrm{Br}$, AA 12: 257.07. See Förster (1987) for ample contextualisation.

${ }^{25}$ OP, AA 21: 524.15-16; 36.

${ }^{26}$ Cf. MAN, AA 04: 468.17-29; 4. 


\section{0}

knowledge of them concerns only contingent knowledge of these outer appearances, only to be acquired by experience, and it is not philosophy but merely an aggregate of perceptions - yet its completeness as a system, is, nonetheless, an object of philosophy. The supreme division of the science of nature [philsophia naturalis] according to its content can be none other than that between its metaphysical foundations, which are founded entirely in concepts of the relation of motion and rest of outer objects, and physics which systematically orders the content of empirical knowledge of them, and which, as stated, has the task of moving toward completeness in its elements - although it cannot count on this certainty. $^{27}$

Scientific laws thus have a double foundation: an empirical one and an $a$ priori one. Similarly, pure experience cannot establish the necessity and universality of a scientific proposition: we can only establish that there is no exception to this or that rule. ${ }^{28}$ In the Opus postumum, Kant objected to the title of Newton's Principia mathematica philosophiae naturalis, of which a more appropriate title should have been Scientiae naturalis principia mathematica ${ }^{29}$, on the grounds that a mathematical foundation is merely instrumental, indirect ${ }^{30}$ and partly based on experience, and thus not properly speaking philosophical:

${ }^{27}$ OP, AA 21: 402.12-26; 14-15 [italics in last sentence added], cf. OP, AA 22: 265.18-22). Original: "Der Begriff von einer Naturwissenschaft (philosophia naturalis) ist die systematische Vorstellung der Gestze der Bewegung der äußeren Gegenstände im Raume und der Zeit so fern jene a priori mithin als nothwendig erkannt werden können; denn das empirische Erkentnis derselben was das Zufallige nur durch Erfahrung erwerbliche Erkenntnis dieser äußeren Erscheinungen betrifft so ist das nicht Philosophie sondern nur ein Aggregat von Warnehmungen dessen Vollstandigkeit als eines Systems doch ein Gegenstand für die Philosophie ist. Die Obereintheilung der Naturwissenschaft ihrem Inhalte nach kann nun keine andere seyn als die in die metaphysische Anfangsgr de derselben die gänzlich auf Begriffen vom Verhältnisse der Bewegung und der Ruhe äußerer Gegenstände gegründet sind und die Physik welche den Inhalt der Erfahrungserkentnis derselben systematisch ordnet welche also wie gesagt mit ihren Elementen auf Vollständigkeit zwar nicht sichere Rechnung machen kann, aber darauf hinzuwirken den Beruf hat."

${ }^{28} \mathrm{KrV}$, AA 03: 29.02-06; 137.

${ }^{29}$ OP, AA 22: 490.08-14; 140.

${ }^{30}$ OP, AA 22: 85.03. 
They are only an instrument (albeit a most necessary one) for the calculation of the magnitude of motions and moving forces (which must be given by observation of nature) and for the determination of their laws for physics (so that the quality of the motions and moving forces can be specified in regard to the central forces of bodies in circular motion [...]) Consequently, this doctrine properly forms no part of the philosophical study of nature. ${ }^{31}$

Natural science (dealing with empirical knowledge and expressed in mathematical terms) is distinct from metaphysics: "both sciences proceed from a priori principles, [but] the difference is that the former does so from intuitions, the latter from a priori concepts - a difference so great that it is as if, in the transition from one to another, reason itself [...] were to displace one into quite different worlds" ${ }^{\prime 32}$. Mathematics supplies "only the application of concepts to intuitions a priori" ("nur die Anwendung der Begriffe auf Anschauungen a priori") ${ }^{33}$. In the Metaphysical Foundations of Natural Science Kant did not separate mathematics from metaphysics. ${ }^{34}$

Kant further divides philosophia naturalis into (i) physica generalis (which deals only with "only the properties of matter

${ }^{31}$ OP, AA $21: 482.04-15 ; 43$, cf. 120.10-12, 123.11-21, 161.03-14, cf. OP, AA 22: 490.05-07; 139, 512.14-15; 151, 519.09-12; 155. Original: “[...] die mathe matis che Anfangsgründe der Naturwissenschaft [...] ist [...] nur ein und zwar sehr nöthiges Instrument die Große der Bewegungen und bewegender Kräfte welche letztere in der Naturbeobachtung gegeben seyn müssen zu schätzen und die Gesetze derselben für die Physik zu bestimmen (so daß die Qualität derselben in Ansehung der Centralkrafte an im Kreise bewegten Korpern [...] angegeben werden können), so daß folglich diese Lehre eigentlich keinen Theil der philosophischen Naturkunde ausmacht [...]".

32 OP, AA 22: 543.17-23; 82-83. Original: "Beyde sind durch eine unüberschreitbare Kluft von einander geschieden und, obzwar beyde Wissenschaften von Principien a priori ausgehen, so ist doch der Unterschied daß die erstere es von A n s chau ngen die zweyte von B e griffen a priori thut so groß, als ob man in dem Übergange von einer zur anderen durch dieselbe Vernunft (denn das bedeutet Erkenntnis a priori) in ganz verschiedene Welten versetzt würde."

${ }^{33}$ OP, AA 22: 240.20-22; 56, cf. 490.22.27; 138-139, 512.11-21; 151, 515.11-13; 153.

${ }^{34}$ Friedman (1992), 222-223. 


\section{2}

[according to Kant the cornerstone ("Anfangsgründe") of the metaphysics of natural philosophy ${ }^{35}$ ] in outer objects" ("nur die Eigenschaften der Materie an äußeren Gegenständen der Erfahrung")) and (ii) physica specialis which "attends to bodies formed from this matter in a particular way, and which draws up a system of them" ("auf die aus jener Materie auf besondere Art geformte Körper sieht und von ihnen ein System aufstellt"). ${ }^{36}$ Kant had indeed dealt with the former in his Metaphysical Foundations, where he had provided a priori derivations of the central concept of physics: matter (and material substance), but he remained silent on the transition to physics. He had addressed physica generalis but not physica specialis. On the relation between both he noted: "there can be a relationship of the one form of knowledge to the other which rests neither entirely on principles a priori, nor on empirical principles" ${ }^{37}$. As the late-Kant wanted to show in full detail how the a priori principles of knowledge were concretized in physics, he took the theoretical deficit of his transcendental doctrine with respect to physica specialis very seriously. He wanted to fill in this gap by rendering explicit how a priori concepts are applied not in metaphysical but in physical-dynamic functions to real bodies such that a system of empirical concepts and laws is arrived at. ${ }^{38}$ However, Kant noticed, there is a leap between metaphysics and physics "[t]hus", he concluded, "there must be mediating concepts which [enable] the transmission from the one doctrine to the other, i.e. the application of $a$ priori concepts to experience in general" ${ }^{\prime 3}$. The metaphysical foundations of science offer no material for physics: "they are divisions for the concept which require to be filled; and mere forms without an underlying

\footnotetext{
${ }^{35}$ OP, AA 22: 166.05 .

${ }^{36}$ OP, AA 21: 407.16-20; 18f. On an unpublished folio of the Opus postumum, Kant distinguished between "dem Elementarsystem der bewegenden Kräfte der Materie" and "dem Weltsystem" (OP, AA 22: 226.08-10).

${ }^{37}$ OP, AA 21: 402.27-403.01-02; 15. Original: “[...] kann es ein Verhaltnis der einen Erkentnisart zu der anderen geben welches weder ganz auf Principien $a$ priori noch auf empirischen" [...].

${ }^{38}$ OP, AA 21: 477.18-20; 41, cf. OP, AA 22: 282.09-11; 101.

${ }^{39}$ OP, AA 21: 311.11-13; 25. Original: "So muß es also Mittelbegriffe geben die blos den Übergang von der einen Naturlehre zur anderen überzuschreiten d. i. zur Anwendung der Begriffe a priori auf Erfahrung überhaupt anzuwenden wie denn die Principien der Moglichkeit der Erfahrung überhaupt selbst a priori gegeben seyn müssen."
} 


\section{3}

material can as little yield a system of experience, as richly distributed material without form" ${ }^{\text {"40 }}$. Moving forces of matter can only be known by experience. The task is then to classify the real objects of nature according to their a priori principles. Such classification would result in a universal doctrine of forces (physiologia generalis).

So, according to the late-Kant, the main philosophical task lay in bridging the broad gulf ("hiatus in systemato") between metaphysics and physics, "the science of the coordination of all empirical representations (all perceptions) into a system or whole" 41 , by means of what he called intermediary concepts ["Mittelbegriffe" ${ }^{42}$ ] "which form a distinctive construction" ("welche ein besonderes Bauwerk ausmacht möglich gemacht werden") $)^{43}$. Kant noted that "a system can never be constructed out of merely empirical concepts" ("[a]us blos empirischen Begriffen kann nie ein System gezimmert werden") ${ }^{44}$ - for indeed, as Kant famously wrote at the beginning of the Critique "[r]eason in order to be taught by nature, must, approach nature with its principles in one hand, according to which alone the agreement among appearances can count as laws, and, in the other hand, the experiments thought out in accordance with these principles" ${ }^{45}$. Eckart Föster has correctly noticed that an important reason why Kant thought that the Critique and his

${ }^{40}$ OP, AA 21: 474.25-28; 39. Cf. Förster (2002), 4. Original: "Es sind Fächer für den Begriff welche man auszufüllen verlangt und bloße Formen ohne einen ihnen untergelegten Stoff können eben so wenig wie ein reichlich hingeworfener Stoff ohne Formen ein Erfahrungssystem abgeben [...]".

41 OP, AA 21: 582.13-16; 90. Original: “[...] die Wissenschaft der Zusammenordnung aller e $\mathrm{mp}$ i $\mathrm{r}$ is $\mathrm{ch}$ en Vorstellungen (aller Warnehmungen) zu einem System [...]".

${ }^{42}$ For instance, according to Kant the concept of moving forces (of matter) has "applications to empirical concepts", but at the same time it can be thought as $a$ priori "according to the relations of the moving forces in space and time, and as such, can be completely classified" (OP, AA 21: 477.07-10; 41).

${ }^{43}$ OP, AA $21: 476.16-17 ; 40$. Friedman does not seem to pay much attention on Kant's attempt to establish moving force as an intermediary concept between metaphysics physics and physics (Friedman (1992), 264). Neither does Förster (Förster (2000), 16).

${ }^{44}$ OP, AA 21: 476.16-17; 40.

${ }^{45} \mathrm{KrV}$, AA 03: 10.21-22; 109. Original: "Die Vernunft muß mit ihren Principien, nach denen allein übereinstimmende Erscheinungen für Gesetze gelten können, in einer Hand und mit dem Experiment, das sie nach jenen ausdachte, [...]". 


\section{4}

Metaphysical Foundations remained incomplete was that they did not "supply physics with a guideline for a systematic investigation of the specific forces in nature" 46 . Kant's final challenge was thus to construct the middle ground between physics and metaphysics. ${ }^{47}$ Part of the transition project consisted in showing how (abstract) matter could be turned into (physical) body. The transition takes place when a priori concepts are applied to real bodies. ${ }^{48}$ In the Metaphysical Foundations, Kant had conceived matter purely mechanically (quantity of matter was estimated by impulse and velocity), that is, he conceived matter merely as that which is movable in space. ${ }^{49}$ In physics, however, we treat matter dynamically, that is we study the moving forces as found in experience (or as Kant puts it "the movable, insofar it has moving force" ("d a s Bewegliche vorstellt so fern es bewegende Kraft hat" $)^{50}$ or "that which makes space an object of the senses" ("das was den Raum zum Gegenstande der Sinne macht") ${ }^{51}$ ). In the Metaphysical Foundations Kant had left out true dynamical forces. ${ }^{52}$ Not surprisingly, in the Opus postumum Kant now stated that quantity of matter can only be estimated dynamically, i.e. by weighing. ${ }^{53} \mathrm{~A}$ condition for moving forces to be able to act is that they act not in a void but in the ether - hence, the importance of the ether proofs in the Opus postumum. ${ }^{54}$ In empty space, no effects of forces could be perceived. Thus: the ether, the substance of which Kant thought it could unify physics, is an a priori given: without space being filled with matter no effect of the moving forces of matter could be sensed. ${ }^{55}$ The ether proofs are therefore a necessary part in Kant's transition project: the ether provides "the topic

\footnotetext{
${ }^{46}$ Förster's editorial Introduction to the Opus postumum (xxxiv). Cf. OP, AA 21: 616.24-26 [italics added]: "Dieser Theil ist der systematische Inbegrif der $a$ priori denkbaren bewegenden Kräfte der Anziehung und Abstoßung mit ihrer Modificationen [...]". Cf. Friedman (2002), 261.

${ }^{47}$ OP, AA 21: 117.01-05

${ }^{48}$ OP, AA 21: 116.01-03.

${ }^{49}$ MAN, AA 04: 537.12-13; 76. Cf. Carrier (2001), 122-123, 134).

${ }^{50}$ OP, AA 22: 190.04-05; 51.

${ }^{51}$ OP, AA 22: 514.01-02; 152.

${ }^{52}$ Friedman (1992), 225.

${ }^{53}$ Ibid., 27-29.

${ }^{54}$ Förster (2000), 92-101.

${ }^{55}$ OP, AA 21: 220.02-03; 70.
} 
15

of the moving forces of matter" ${ }^{256}$. The ether was both a physical entity as well as a priori condition of our perception of dynamical forces.

On a separate leaf, he began stating his solution to the bridgingproblem:

Therefore the transition from metaphysics to physics, from the $a$ priori concept of movable in space (i.e. the concept of matter in general) to the system of moving forces, can [proceed] only by means of that which is common to both - by means of the moving forces insofar as they act not on matter but rather united or opposed among one another, and thus form a system of the universal doctrines of forces (physiologia universalis) which stands between metaphysics and physics. Insofar as it contains for itself a system of the application of a priori concepts to experience, i.e. the investigation of nature, it combines metaphysics with physics in a system. ${ }^{57}$

Kant suggested that all physical forces in rerum natura are "contained in the concepts of motion as active cause [i.e. moving force]" ("in dem Begrif der Bewegung als wirkender Ursache enthalten") ${ }^{58}$. According to Kant, the concept of 'moving force' can be thought of a priori according to the relations of moving forces in space and time and can thus be completely classified.$^{59}$ The concept of 'moving force' (regulated by $a$ priori principles) serves as an intermediary concept ['Mittelbegrif'] that could be interpreted empirically. In other words, all concrete physical forces are regulated by the concept of 'moving force', a concept which in its turn is regulated by a priori principles. The concept of 'moving force'

\footnotetext{
${ }^{56}$ Förster (2002), 99.

${ }^{57}$ OP, AA 21: 478.16-26; 42 [italics added]. Original: "Also kann der Ubergang von der Met. zur Physik von dem Begriffe a priori des Beweglichen im Raum d. i. dem Begrif einer Materie überhaupt zu dem System der bewegenden Kräfte nur durch das was beyden Gemein ist durch die bewegende Kräfte so wie sie nicht eben auf die Materie sondern unter einander vereinigend oder entgegengesetzt wirken und so ein System der allgemeinen Kräftenlehre (physiologia generalis) bilden welche zwischen der Met. und Phys. zwischen inne steht und indem sie für sich ein System der Anwendung der Begriffe $a$ priori auf Erfahrung d. i. der Naturforschung enthalt das erste mit dem letzteren in einem System verbinden."

${ }^{58}$ OP, AA 21: 387.09-10; 13.

${ }^{59}$ OP, AA $21: 477.07-14 ; 41$.
} 


\section{6}

thus stands between metaphysics and physics: it is regulated by $a$ priori principles and given content by empirical observation. It is difficult to say whether Kant was ultimately satisfied with this solution: he never laid down his efforts at the printer's.

\section{Whewell's answer to the Kantian gap}

I shall first, document Whewell's references to Kant in his philosophical notebooks (3.1). Secondly, I shall argue that Whewell, who took Kant's philosophy as a point of departure for his doctrine of Fundamental Ideas, was unsatisfied with Kant's philosophy of science because it did not show how 'modifications' (in the sense of concretizations) of a priori principles resulted in empirical laws and that he correspondingly tried to modify the Kantian project (3.2). In other words, according to Whewell, Kant had not solved the bridging problem. Nowhere in the following do I claim that Whewell was a Kantian. For instance, Whewell did not want to provide an extensive list of a priori principles, as he allowed that new Fundamental Ideas would emerge in the course of the history of science. The significance of Kantianism for Whewell's philosophy has often been discussed in the literature. ${ }^{60}$ In defence of such significance, Robert E. Butts has claimed that Whewell "owes his theory of science to Kant" This is clearly an overstatement since Whewell was aware of the limitations of Kantianism and criticised it for not being able to solve the bridging-problem. Menachem Fisch and Laura J. Snyder have denied a substantial significance of Kant on Whewell's philosophy. Menachem Fisch has pointed out that in Whewell's notebook we cannot find any of the questions raised in the Critique.$^{62}$ Recently, Laura J. Snyder claimed that Whewell's philosophy is not derived from, nor greatly influenced by

\footnotetext{
${ }^{60}$ See Butts (1965), 162-164, Fisch (1985), 279 (footnote 19), Snyder (2006), 44-47, and Yeo (1979), 500. For Whewell's own criticisms on Kant, see Whewell (2001 [1860]), VII, 312-314, 334-336). For Whewell's published work I have consulted: Collected Works of William Whewell (16 vols.), Ed. R. Yeo. Bristol: Thoemmes Press. Convention: between square brackets, I refer to the year in which the first edition of a work of Whewell appeared. I also add the volume-numbers of each work in the 2001 edition of Collected Works of William Whewell.

${ }^{61}$ Butts (1994), 278.

${ }^{62}$ Fisch (1991), 105.
} 
Kant. ${ }^{63}$ In the following, I will temper the claims of Fisch and Snyder without resorting to a naive picture of Whewell as 'the English Kant'. The account I defend is more complex. More precisely, I shall argue that Whewell's philosophical position developed in close dialogue with Kantian philosophy and should be seen as an answer to the bridgingproblem that could not, according to Whewell, be answered by Kant. Finally, we shall look at his doctrine of Fundamental Ideas as he later developed it (3.3).

\subsection{Kant: a philosophical point of departure for Whewell's philosophy}

Whewell's inclination toward Kantian philosophy and his familiarity with it can easily be gathered from several of his notebooks which were written between ca. 1830 and $1833 .{ }^{64}$ For instance, in notebook five (dated around 1832), Whewell noted that "Kant had left nothing in the wide world of being but certain X's, - things in themselves, without

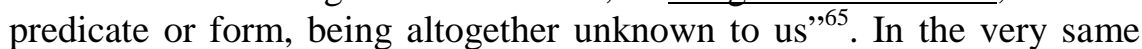
notebook, he left notes ${ }^{66}$ on Kant's Kritik der praktischen Vernunft of which the influence can be traced in the section entitled "Of Practical Skill and of Speculative Knowledge" in the sixth notebook. In the sixth notebook, Whewell also drew on Kant's Kritik der reinen Vernuft ${ }^{67}$, as is clear from the following statement:

\footnotetext{
${ }^{63}$ Snyder (2006), 51.

${ }^{64}$ Several notebooks, contained in the larger collection of Whewell Papers (henceforth "WP"), are preserved and can be consulted at Trinity College Cambridge, Wren Library (Whewell Papers, class-mark R.18.17). Convention: words or text between arrows pointed downwards refer to additions inserted from above; words or texts between arrows pointed upwards refer to additions inserted from below. It should be noted that some notebooks are numbered as books others as folios (foliated notebooks are always preceded by "f.").

${ }^{65} \mathrm{WP}, \mathrm{R} .18 .17^{5}, 125$ [underscore in original].

${ }^{66}$ Ibid., 181, 183, 184.

${ }^{67} \mathrm{Cf}$. Whewell's notes on the Kritik der reinen Vernuft composed between 18 and 23 December 1825 (WP, R.18.9 ${ }^{13}$, f. 10r, f. 11r). In these folios, Whewell made notes on the distinction between analytical and synthetical knowledge, synthetic a priori judgements, intuition (Anschauung), transcendental knowledge, and the possibility of a priori synthetical principles, mathematics, science and metaphysics. Whewell first mentioned the Kritik der reinen Vernunft on 9 February 1821 (WP, R. $18.9^{8}$, p. 15 , also on 24 October 1821 : WP, R.18.9 , f. $41 \mathrm{v}$,
} 
The conditions of our perceptions, in consequence of $\mathrm{w}^{\text {ch }}$ we apprehend objects as existing in space and time, are capable, as we have seen, of giving truth to extensive and important sciences, that is, systematically arranged trains of speculative truth. But these conditions of our perception show themselves in another way, in which indeed, they operate $\downarrow$ by $\downarrow$ far $\downarrow$ the $\downarrow$ most extensively; and

f. $42 \mathrm{r}$ (on this folio Whewell wrote "sensitive faculty - understanding - practical reason")). In WP, R.19 14 , ff. 1r-5r, ff. 6r-7v, Whewell composed more detailed notes on the Kritik der reinen Vernunft (these were written between 25 July and 8 September 1827). On f. 2 r, he wrote: "The object of this celebrated work is to show the possibility of knowledge i.e. of universal and necessary truths." Empirical knowledge in its own nature does not give necessity but only limited information. Hence, "the grounds of such knowledge must be sought in the constitution of the mind". The powers of the mind are twofold: sensation and thought. Whewell noted that in sensation we have the conception of space and time and cause and effect, that these conceptions are not derived from experience, and express the "laws (forms) of our perceptive power" (ibid., also: f. 4r, f. 7r [underscore added]). The faculty of Reason provides us with various conceptions of understanding (Verstandesbegriffe) which enter into all our judgements and which can be enumerated as categories (ibid. f. 2 r, also: f. $3 \mathrm{v}$ ). The categories "give unity to the synthesis of a complex representation by $\mathrm{w}^{\mathrm{h} .}$ we comprehend its parts in one act of knowledge" (ibid., f. 2r-v [underscore added], also WP R. $18.17^{10}$, p. 3). These conceptions are "of an a priori validity when applied to objects: that is we cannot learn anything respecting objects without its being included in them" (WP, R.19 ${ }^{14}$, f. $2 \mathrm{v}$ ). Moreover, experience is only possible by means of such conceptions (ibid., also: f. 4r). Representations are connected in the mind in a synthetic unity by the act of apperception: "[i]n order to have any knowledge we must excercise a synthetical operation belonging to ourselves" (ibid., f. 3r). On the category of cause he added: "But in time, $\mathrm{w}^{\mathrm{h} .} \mathrm{I}$ assume as a ground of perception, I represent to myself a synthetical unity of what is complex, without $\mathrm{w}^{\text {h. }}$ the relation of sequence could not be given. But this unity, as a condition of the conception of sequence omitting time, is the category of cause."'(ibid., f. 4r [underscore added], also: f. 7r). In the case of the perception of an object which has no homogeneous nature, the categories are applied by means of "general notions (abstract ideas) $\mathrm{w}^{\mathrm{h}}$ are homogeneous with the categories on one hand \& with perceptions on the other". Kant refers to these general notions by the term "schemata of the Understanding" (ibid., f. 4v). Whewell also made some further notes on analytical and synthetical judgement and concluded his notes with: "The conceptions of the understanding acquire meaning of being referred to objects." (ibid., f. 5r). 


\section{9}

which, indeed, for various reasons, we might may consider as the primary use of this part of our internal constitution. The apprehension of things as existing and occurring in space and time, regulates every action of every principal creature. ${ }^{68}$

Whewell learned from Kant's philosophy the importance of the active powers of reason (pace Snyder). He noted that "the German system" has "not merely a tie connecting the impressions which we progressively receive, but a constitution of the active faculties which makes the impressions impossible without the connexion" ${ }^{69}$. He stressed that in order to know we must perceive and conceive. Knowledge implies both passive as well as active thought: "collection of impressions" and "the operations of the reason". ${ }^{70}$ The actions of the mind work on impressions provided by the senses. ${ }^{71}$ Whewell noted that by using language "we do not expose our impressions only, but expose them modified and transformed by the operations of our thoughts" ${ }^{72}$, so that human minds are "perpetually exercising a formative and productive power" ", which is "exercised upon the rude material" ". Such principles, which "are part of the original furniture of the common or unsystematic reason" $" 75$ and which spell out " $\downarrow$ universal $\downarrow$ and familiar modes of contemplating objects"76, have been brought to light and systematized during the course of human history. According to Whewell, "sound and real physical science consists in apprehending a general fact of observation by means of $\downarrow$ distinct $\downarrow$ ideas" 77 . Whewell warned that he did not use the term "idea" in its customary sense and noted that "the ideas of which I have to speak are general notions of relation, connexion, dependence, by which $\downarrow$ such $\downarrow$

${ }^{68}$ WP, R. $18.17^{6}, 13$. Also see R.18.17, 43.

${ }^{69} \mathrm{WP}, \mathrm{R} .18 .17^{9}, 11$.

${ }^{70}$ WP, R. $18.17^{8}$, f. 19 r.

${ }^{71}$ Ibid., f. 36v.

${ }^{72}$ WP, R.18.17, 23 . About 1821 , Whewell noted - although not yet endorsing Kantianism - that in Kant's philosophy the representation of the external world consists of "a modif. ${ }^{\mathrm{c}}$ of the mind $\mathrm{w}^{\mathrm{ch}}$ may exist without being known" (WP, R.18.17 $\left.{ }^{1}, 105\right)$.

${ }^{73}$ WP, R. $18.17^{7}, 24$.

${ }^{74}$ Ibid., 41.

${ }^{75}$ Ibid., 14.

${ }^{76}$ Ibid., 18.

${ }^{77}$ Ibid., 61, also: 63 [italics added]. 
conceptions are combined with one another" ${ }^{78}$. Such ideas or conceptions involve "an act of the mind by which it gives a certain unity $\downarrow$ to each $\downarrow$ of the groups of things so seemed"; furthermore, "[t]his act may be expressed by saying that we conceive the objects as one, and the faculty of the mind may be called conception",79. In other words, "the perceptions of this faculty of perceiving acts, are bound together by conceptions which give them unity" 80 .

Kant's transcendentalism was important to Whewell since it implied a shift from practical to contemplative "attention". Kantianism, for Whewell, was a "contemplative" exercise that rendered explicit the conditions which are presupposed by our (practical) perceptions:

The principles which had been followed through the investigation of practical propensities, might come to be the objects of a contemplative attention; and men, not content with the safeconduct $\downarrow$ which they enjoy from $\downarrow$ their practical perceptions, $\downarrow$ faithful $\downarrow$ but silent guides, might begin to ask and answer concerning the path they were pursuing. They might turn their attention from the object to the method $;^{81}$

In several of these notebooks, Whewell sought to unravel "the general fundamental convictions and laws" ${ }^{82}$ underlying human reasoning and science. His aim was to show how these laws or principles gave rise to sound scientific knowledge:

Our object is to ascertain the $\downarrow$ general $\downarrow$ laws which govern the formation and progress of knowledge in the largest sense; And the course which we purpose to follow leads us to examine their $\downarrow$ laws $\downarrow$ in the first place, as they have operated in those branches of human knowledge which more peculiarly termed Sciences, and in which the certainty and progressive character of our knowledge are most striking and incontestable. [...] Science may be $\uparrow$ for our purpose $\uparrow$ described as speculative knowledge of general truths ${ }^{83}$

\footnotetext{
${ }^{78}$ Ibid., 61.

${ }^{79}$ WP, R. $18.17^{8}$, f. 15 r [underscore in original]; cf. R. $18.17^{10}, 3$.

${ }^{80}$ WP, R. $18.17^{8}$, f. 16 r, cf. f. $32 \mathrm{v}$.

${ }^{81}$ WP, R. $18.17^{6}, 33$.

82 Ibid., 12.

${ }^{83}$ Ibid., 84 [underscore in original].
} 
On space and time Whewell noted that "all things are presented to our apprehension under the conditions of space and time" ${ }^{\$ 4}$. Space and time are intuitions. When using the word "intuition" he used it as an equivalent to "the German word Anschauung" 85 . He noted that "[s]pace is not a notion obtained by experience" ${ }^{96}$ and that "the existence of space as a real and necessary condition of all objects as perceived"87. On time he wrote: "Time is a necessary condition in the presentation to our minds of all occurrences" 88 . Space, time, causation (and "the like") express relations between our impressions. ${ }^{89}$ The concept of cause is not derived from experience. ${ }^{90} \mathrm{He}$ wrote the following on Kant's account of the idea of cause:

While this series of disputes was going on in Scotland [Whewell is referring here to Hume, Stewart, and Brown], a great metaphysical genius $\downarrow$ in Germany $\downarrow$ was evolving his solution of the same problem. Kant's speculations originate, as he informs us, in the trains of thought to which Hume's writings gave rise, and the Critik [sic] der Reinen Vernunft, an examination of the pure Reason was published in 1781, with the view of showing the true nature of our knowledge. [...] According to Kant, causality is a condition of our experiences; a connexion in events is requisite to our apprehending them as events; [...] The $\downarrow$ relation $\downarrow$ of causation is a condition of our thinking of things, as the relations of space are a condition of our seeing them. ${ }^{91}$

These conditions "reside in the constitution of the mind" 92 and are the "conditions of experience",93, "Conditions of Inductivity"," "Regulative $\&$ Interpretative Conceptions",

\footnotetext{
${ }^{84} \mathrm{WP}, \mathrm{R} .18 .17^{7}, 12$.

${ }^{85} \mathrm{WP}, \mathrm{R} .18 .17^{8}$, f. $67 \mathrm{v}$ [underscore in original].

${ }^{86}$ Ibid., f. $38 \mathrm{v}$.

${ }^{87}$ Ibid., f. 42 r, cf. f. $58 \mathrm{v}$.

${ }^{88}$ Ibid., f. $56 \mathrm{v}$.

${ }^{89}$ WP, R. $18.17^{7}, 16,18$. In a letter to Richard Jones, 21 August 1834, Whewell used the term "ideal relations" (WP, Add. Ms. c. $51^{175}$, f. $1 \mathrm{v}$ ).

${ }^{90} \mathrm{WP}, \mathrm{R} .18 .17^{9}, 6$.

${ }^{91}$ Ibid., 10. On 11, Whewell wrote down the following reference to the Critique of Pure Reason: "K.R.V. p. 170".

${ }^{92} \mathrm{WP}, \mathrm{R} .18 .17^{8}$, f. $41 \mathrm{v}$.

${ }^{93}$ Ibid., f. 43 r.
} 
In notebook nine, Whewell set out to find an answer to the following paradox: if mechanics has empirical content how can it be necessary? In other words, "[i]n the phraseology usual among German writers" his aim was "to prove the possibility of the science of mechanics" $" 97$ (pace Fisch). However, according to Whewell, the Kantian account of the idea of cause, which is "indispensably true as far as it goes", "requires further explanation". ${ }^{98}$ The notion of cause must be expressed "in the form of propositions in order that they may form a foundation for our reasonings" 99 . In other words, we must be able "to lay down certain Axioms, or Definitions which may be seen as Axioms, in order that we may have such a structure of Demonstration concerning causation in any of its modifications" ${ }^{\prime 100}$. Whewell drew a close analogy between the axioms of mechanics and the axioms of geometry: "The axioms of $\downarrow$ mechanics $\downarrow$ do, in fact, flow from our idea of cause, as necessarily as the axioms of geometry $\downarrow$ do $\downarrow$ from our intuition of space." 101 . He then continued to show that the statement "that everything which happens must have a cause" is a partial expression of our idea of cause ${ }^{102}$, but that "we still have to show how it enters into the construction of the mechanical sciences" $" 103$. Whewell's solution consisted in uncovering the Axioms of Causation which serve as general intermediate forms and could be given empirical content (see 3.2). In the case of mechanics, the Idea of Cause is modified into and concretized by the Idea of Force. Whewell clearly took over the idea of Kant that scientific knowledge derives from a priori principles. Nevertheless, he was dissatisfied with Kant's failure to show how these a priori principles enter into the construction of science. In other words, according to

\footnotetext{
${ }^{94}$ WP, R. $18.17^{11}$, f. 1r, f. 30r.

${ }^{95} \mathrm{WP}, \mathrm{R} .18 .17^{13}$, f. c. $75 \mathrm{r}$.

${ }^{96} \mathrm{WP}, \mathrm{R} .18 .17^{11}$, f. $75 \mathrm{v}$.

${ }^{97}$ WP, R. $18.17^{9}, 2$.

${ }^{98}$ Ibid., 12.

${ }^{99}$ Ibid.

${ }^{100}$ Ibid. [italics added].

${ }^{101}$ Ibid., 32.

${ }^{102}$ He noted: "This Axiom expresses only a result, a consequence, $\downarrow$ a derivative $\downarrow$ of our idea of cause, a portion of the convictions which accompany it. The Axiom may be requisite in the exposition of our knowledge, but the idea itself is the foundation of the knowledge." (ibid., 14).

${ }^{103}$ Ibid. [underscore in original; italics added].
} 
Whewell, Kant had failed to provide bridging principles between the a priori principles and scientific laws which have empirical content.

\subsection{The 1834 paper on the necessity of the laws of mechanics}

In these notebooks (especially the eighth and ninth notebook), we find the materials that Whewell systematized into an important paper entitled $O n$ the Nature of the Truth of the Laws of Motion (1834) which was published shortly after the composition of these notebooks. The paper itself does not indicate that Whewell saw his solution as an improvement of Kantian natural philosophy. If, however, we juxtapose the notebooks and the paper, this becomes more obvious. In his 1834 paper Whewell's focus is on mechanics. Since the science of mechanics studies the causes (i.e. the forces) of motions, they depend on the universal principles presupposed in all our reasoning concerning causes. ${ }^{104}$ In other words, the truth of the laws of motion depends upon the principles applied in our everyday reasoning concerning causes. ${ }^{105}$ These principles of causation are expressed by means of the following three axioms:

Axiom I. - Every change is produced by a cause.

Axiom II. - Causes are measured by their effects.

Axiom III. - Action is always accompanied by an equal and opposite Reaction. ${ }^{106}$

Inevitably and unconsciously we assume the truth of these axioms whether for practical or theoretical purposes. These axioms are necessarily true according to "our notions of material causation"107 and are "the universal and necessary rules of causation"108. Now, each of the laws of motion corresponds to and is based on the forms of these axioms:

\footnotetext{
${ }^{104}$ In notebook nine he noted that Newton's law has empirical content and depends "upon our conceptions and the ideal relations under which they are inevitably attained" (ibid., 42).

${ }^{105}$ Whewell (2001 [1840]), V, 574. The paper occurred as a reprint which was added to the Philosophy of the Inductive Sciences. All references are to this reprint.

${ }^{106}$ Ibid., 574-576; cf. ibid., IV, 177-185.

${ }^{107}$ Ibid., V, 591.

${ }^{108}$ Ibid.
} 
the first law states that a body not acted upon by any force will go in a straight line with an invariable velocity (or put positively, that each non-inertial motion is caused by an impressed force); the second that, when an impressed force acts, its accelerative quantity is measured by the accelerative effect produced; and the third that, when one body acts upon another, there will be an equal and opposite reaction-force. From this Whewell concluded:

And so far as the laws are announced in this form, they will be of absolute and universal truth, and independent of any particular experiment or observation whatever. But though these laws of motion are necessarily and infallibly true, they are, in the form in which we have stated them, entirely useless and inapplicable. It is impossible to deduce from them any definite and positive conclusion, without some additional knowledge or assumption. ${ }^{109}$

What the precise cause of retardation is in the actual motions of bodies, how we should measure the accelerative effect, and how we should measure the action (i.e. the motive force ${ }^{110}$ ) can only be established by observation. ${ }^{111}$ Whewell wrote:

The form, and even the language of these laws is of necessity what it is; but the interpretation and application of them is not possible without reference to fact. We may imagine many rules according to which bodies might move (for many sets of rules, different from the existing ones, are, so far as we can see, possible) and we would still have to assert - that velocity could not change without a cause - that change of action is proportional to the force which produces it, - and that action and reaction are equal and opposite. The truth of these assertions is involved in these notions of causation and matter, which the very attempt to know anything concerning the relations of matter and motion presupposes. ${ }^{112}$

\footnotetext{
${ }^{109}$ Ibid., 577 [italics added].

${ }^{110}$ According to Whewell, the motive force can be measured by both $m v$ (in case we want to measure it by the effect produced in a given time) and $m v^{2}$ (in case we want to measure the whole effect produced) (ibid., 585).

${ }^{111}$ Ibid., 576-588.

${ }^{112}$ Ibid., 588.
} 
The laws may be considered as a formula derived from $\grave{a}$ priori reasonings, where experience assigns the value of the terms which enter into the formula. ${ }^{113}$

The laws of motion thus have both an empirical part and necessary part (which cannot be denied without self-contradiction, and, which is derived from a priori principles):

The parts of the laws which I have stated as empirical, appear to me to be clearly of a different nature, as to the cogency of their truth, from the parts which are necessary; and the difference is, I think, established by the fact that these propositions were denied, contested, and modified, before they were finally established. If these truths could not be denied without a self-contradiction, it is difficult to understand how they could be (as they were) long obstinately controverted by mathematicians and others fully sensible to the cogency of necessary truths. ${ }^{114}$

Whewell's Axioms served as intermediary concepts. It is important to note that Whewell consistently endorsed this interpretation in his later work (esp. in the Philosophy of the Inductive Sciences). The content of his solution never changed. What did change, however, was its domain of application.

3.3. Whewell's generalisation of the 1834 solution: the Philosophy of the Inductive Sciences (1840)

As we have seen, in the 1834 paper Whewell's focus was on mechanics. When he had finished his grand historical study on the history of the inductive sciences (1837), he generalized this solution to other domains of science which have progressed according to other Fundamental Ideas. The idea was that the laws arrived at in all other sciences were also necessary (because they derive their form from the Axioms of their corresponding Fundamental Idea) and empirical (because they are interpretations concretizations or 'modifications' of their Axioms).

One of the most prominent goals of Whewell's Philosophy of the Inductive Sciences was to show the place which Ideas have had in the

\footnotetext{
113 Ibid., 594.

${ }^{114}$ Ibid., 593.
} 
progress of science and in the discovery of new truths about the natural world. ${ }^{115}$ As each branch of science progressed, a Fundamental Idea was made more explicit. Some ideas are peculiar to one branch, others are common to more. For example, in the development of mechanics the Ideas of Force, Matter, and Cause are quintessential; in the Chemical Sciences, The Idea of Polarity, Chemical Affinity, and Substance; in crystallography, the Idea of Symmetry; in the Classificatory Sciences, the Idea of Resemblance and Natural Affinity; in the Physiological Sciences, the Idea of Assimilation, Irritability and Final Cause, etc. The progress of science, according to Whewell, was only possible by the fruitful combination of both metaphysics and experience ${ }^{116}$ : "the metaphysical is a necessary part of the inductive movement" ${ }^{117}$. Consequently, the progress of science has its place in observation, in the application of Ideas (which regulate our active operations of the mind ${ }^{118}$ ), and in the union of the two. ${ }^{119}$ Great discoverers are distinguished from barren speculators "not by having no metaphysics in their heads, but by having good metaphysics while their adversaries had bad; and by binding their metaphysics to their physics, instead of keeping the two asunder" ${ }^{120}$. Whewell referred to this

\footnotetext{
115 Ibid., 117.

116 According to Whewell the theory of Fundamental Ideas circumvented Hume's problem of induction: "Our inference from Hume's observation is, not the truth of his conclusion, but the falsehood of his premises; - not that therefore, we can know nothing of the natural connexion, but that, therefore, we have some other source of knowledge than experience; - not, that we can have no idea of connexion or causation, because in his language, it cannot be the copy of an impression; but that since we have such an idea, our ideas are not the copies of our impressions." (ibid., IV, 75). The Idea of Cause warrants the necessary connection between cause and effect, which is by itself not given by experience.

${ }^{117}$ Ibid., IV, ix.

${ }^{118}$ Ibid., 66.

${ }^{119}$ Ibid., ix. Later in his On the Philosophy of Discovery Whewell would write: "They [the Fundamental Ideas] are not proved in the course of scientific investigations, but brought to light as such investigations showed their necessity. They are not the results, but the conditions of experimental sciences. [...] They are not the consequences of knowledge, acquired from without, but the internal condition of our being able to know." (Whewell (2001 [1860]), VI, 349-350 [italics added]).

${ }^{120}$ Whewell (2001 [1840]), IV, x.
} 


\section{7}

necessary intertwinement of ideal and empirical elements for the constitution of knowledge as "the Fundamental Antithesis of Philosophy": knowledge about the world always involves both "Thoughts and Things". ${ }^{121}$ In every acquisition of human knowledge "there must be some thing about which I know, and an internal act of me who know" When Kepler discovered the elliptic orbit of planets, he applied the concept of ellipse to the motion of Mars. The elliptical orbit is constructed and supplied by the mind. We see through ideas, even if we are unaware of them. ${ }^{123}$ Theory and fact can only be separated from each other in terms of the ways wherein they are contemplated: "for a Theory (that is, a true theory) may be described as a Thought which is contemplated distinct from Things and seen to agree with them; while a Fact is a combination of our Thoughts with Things in so complete agreement that we do not regards them as separate" ${ }^{124}$. Fundamental Ideas are at the heart of Whewell's philosophy of knowledge and they perform the same role as Kant's synthetic a priori. It should be noted that Whewell used the term "Idea" in a rather unconventional manner:

But it may suffice to observe that we use the word Ideas, in the manner already explained, to express that element, supplied by the mind itself, which must be combined with Sensation in order to produce knowledge. For us, Ideas are not Objects of Thought, but rather Laws of Thought. Ideas are not synonymous with Notions; they are Principles which give our Notions whatever they contain of truth. ${ }^{125}$

\footnotetext{
${ }^{121}$ Cf. "Without Thoughts there could be no connexion; without Things, there could be no reality. Thoughts and Things are so intimately combined in our Knowledge, that we do not look upon them as distinct. One single act of the mind involves them both, and their contrast disappears in their union." (ibid., 18; cf. Whewell (2001 [1860]), VI, 480). The expression "Fundamental Antithesis of Philosophy" was coined in Whewell's first memoir (1844) (appended to Whewell, (2001 [1840]), V, 647-668).

${ }^{122}$ Ibid., IV, 17; cf. ibid., 666-667.

${ }^{123}$ Ibid., 40.

${ }^{124}$ Ibid., 24, cf. 40.

${ }^{125}$ Ibid., 29.
} 
These Fundamental Ideas are conditions "without which the external world can neither be observed nor conceived" ${ }^{126}$; they "necessarily impose their conditions upon that knowledge of which observation supplies the material" "27. The goal of The Philosophy of the Inductive Sciences was to "not merely to prove that there are such Fundamental Ideas or Laws of mental activity, but to enumerate those of them which are involved in the existing sciences" 128.

In the Philosophy of the Inductive Science, Whewell reiterated his ideas on space, time and causation. Space and time are necessary forms belonging to our perceptive power. We cannot conceive of objects or events as not occurring in space or in time. They are, properly speaking, intuitions: we conceive events occurring in the same absolute space and time. ${ }^{129}$ The Idea of Time (like all other Fundamental Ideas) is a constitutively necessary condition of knowledge ${ }^{130}$ :

By considering time as a form which belongs to our power of apprehending occurrences and changes, and under which alone such experience can be accepted by the mind, we explain the necessity, which we find to exist, of conceiving all such changes as happening in time; and we thus see that time is not a property perceived as existing in objects, or as conveyed to us by the senses; but $a$ condition impressed upon our knowledge by the constitution of the mind itself; involving an act of thought as well as an impression of sense. $^{131}$

Whewell made similar statements on the Idea of Space:

As we have before seen that our knowledge of solid space and its properties is not conceivable in any other way than as the result of a mental act, governed by conditions depending on its own nature; so it now appears that our perception of visible figures are not

\footnotetext{
${ }^{126}$ Ibid., 76.

${ }^{127}$ Ibid., 79.

${ }^{128}$ Whewell (2001 [1958]), VI, 489.

${ }^{129}$ Whewell (2001 [1840]), VI, 89-91, 128-129.

${ }^{130}$ Ibid., V, 633.

${ }^{131}$ Ibid., IV, 127 [italics added]. Cf. Fundamental Ideas are the result of "a particular constitution and activity of the mind, which is independent of all experience in its origin, though constantly combined with experience in its exercise" (ibid., 84, cf. 96).
} 
obtained without an act performed under the same conditions. The sensations of touch and sight are subordinated to an idea which is the basis of our speculative knowledge concerning space and its relations; and this same idea is disclosed to our consciousness by its practically regulating our intercourse with the external world. ${ }^{132}$

By means of the Idea of Cause (which is also not derived from experience and which occupies centre-stage in the mechanical sciences) we constantly perceive the world around us in terms of successions of causes and effects. The empiricist cannot explain the necessary and universal truths ${ }^{133}$ attained in mechanics:

The idea of cause, like the ideas of space and time, is a part of the active powers of the mind. The relation of cause and effect is a relation or condition under which events are apprehended, which relation is not given by observation, but supplied by the mind itself. ${ }^{134}[\ldots]$ We have, in the Mechanical Sciences, certain universal and necessary truths on the subject of causes. Now any view which refers our belief in causation to mere experience or habit, cannot explain the possibility of necessary truths, since experience and habit can never lead to a perception of necessary connection. ${ }^{135}$

\footnotetext{
${ }^{132}$ Ibid., 124-125, cf. 86-87, 111, 127. Since they define the necessary conditions of our perception, the negation of such necessary conditions cannot even be conceived of: "As I have already said, necessary truths are those in which we not only learn that the proposition is true, but see that is must be true; in which the negation of the truth is not only false, but impossible; in which we cannot, even by an effort of imagination, or in a supposition, conceive the reverse of that which is asserted." (ibid., 55; cf. Whewell (2001[1860]), 338). We cannot for instance other than conceive of an object that does not occur in space or time.

${ }^{133}$ See especially Part I, Chapter VIII "Of the Paradox of Universal Propositions Obtained from Experience" (Whewell (2001[1840]), IV, 245-245).

${ }^{134}$ According to Whewell, this opinion was anticipated by Kant "the great metaphysical genius" who thought that "the Relation of Causation is a condition under which we think of events, as the relations of space are a condition under which we see objects" (ibid., 173).

${ }^{135}$ Ibid., 176-177 [italics added].
} 
Perceiving the world in terms of successions of causes and effects is also "a condition of our apprehending successive events" 136. Whewell considered Fundamental Ideas as the conditions under which we think of events. ${ }^{137}$ The necessity and universality of truths is derived "from the Fundamental Ideas which those truths involve":

These ideas entirely shape and circumscribe our knowledge; they regulate the active operations of our minds, without which our passive sensations do not become knowledge. They govern these operations according to rules which are not only fixed and permanent, but which may be expressed in plain and definite terms; and these rules, when thus expressed, may be made the basis of demonstrations by which the necessary relations imparted to our knowledge by our Ideas may be traced to their consequences in the most remote ramifications of scientific truth. ${ }^{138}$

A Fundamental Idea can only be partially described by means of Axioms, i.e. "enunciations of the necessary and evident conditions imposed upon our knowledge by the Fundamental Ideas which it involves"139. From these Axioms we derive propositions that are applicable to the empirical world. ${ }^{140}$

In the Philosophy of the Inductive Sciences, Whewell generalized his ideas on the necessity of the laws of mechanics to other laws in different branches of science. It should be noted that he remained very vague as to what axioms guided other sciences. On how, for instance, the Idea of Polarity could be enunciated in axiomatic terms which are subsequently interpreted empirically, Whewell was never explicit. It therefore remains unclear how his treatment could be extended to other scientific disciplines.

To conclude this section, I clarify that Whewell's philosophy of knowledge in his Philosophy of the Inductive Sciences involved two different types of necessity: (1) one which obtains between a Fundamental Idea and its corresponding Axiom (constitutive necessity), and (2) another which obtains between Axioms and scientific theorems

\footnotetext{
${ }^{136}$ Ibid., 176.

${ }^{137}$ Ibid., 173.

${ }^{138}$ Ibid., 66, cf. 217.

${ }^{139}$ Ibid., 67.

${ }^{140}$ See ibid., 21, cf. 73.
} 
31

or laws (interpretative necessity). ${ }^{141}$ Human beings can only know a Fundamental Idea partially by its Axioms. We can only obtain some glimpses of Fundamental Ideas, under the aspect of Axioms. The Axioms are necessary because they give a partial description of the constitutively necessary conditions of our perception. In other words, what they describe is constitutively necessary of our nature as experiential beings. This notion of necessity can be described as follows:

Constitutive Necessity: Axioms are necessarily true because they partially describe a corresponding Fundamental Idea, which refers to the constitutively necessary conditions of our knowledge of the world.

By contrast, the laws of motion are necessary from their being interpretations of the Axioms of Causation. For instance, the second law of motion, which asserts that forces are measured by their accelerative effects, is an interpretation of the Axiom according to which effects are measured by their effects. It is an interpretation because it instantiates the form of the Axiom and also because it concretises the general terms "cause" and "effect" into empirical counterparts. Such concretization is necessary to arrive at proper knowledge of the world:

It must be allowed, on the other hand, that so long as these formulae are not interpreted by real study of nature, they are nor only useless but also prejudicial; filling men's mind minds with vague general terms, empty maxims, and unintelligible abstractions, which they mistake for knowledge. ${ }^{142}$

This aspect of Whewell's concept of necessity can thus be described as follows:

Interpretative Necessity: The laws of nature are necessary because they are empirical interpretations of necessary Axioms, i.e. they add the required empirical contents to the

\footnotetext{
${ }^{141}$ For a complete outline of the argument I refer the reader to Ducheyne (to appear), wherein I argue against previous accounts of Whewell's account of necessity and provide a coherent alternative.

${ }^{142}$ Whewell (2001 [1840]), IV, 250.
} 
32

abstract form of the Axioms in order to arrive at scientific laws.

As the Axioms of Causation get their interpretation from the material provided by phenomena, they become laws of motion. ${ }^{143}$ Taken jointly, the concept(s) of necessity that are present in Whewell's Philosophy of the Inductive Sciences can be described as follows:

Constitutive and Interpretative Necessity: The laws of nature are necessarily true because they are empirical interpretations of necessary Axioms which derive ultimately from the constitutively necessary conditions of our knowledge of the world, i.e. from Fundamental Ideas.

\section{In conclusion}

In Whewellian terminology, we might say that Kant, in his published works, only had addressed constitutive necessity and not interpretative necessity, i.e. he did not show how a priori principles could be given empirical content by intermediary concepts. With his analysis of the laws of nature as empirical instantiations and concretizations of the Axioms that partially reveal their corresponding Fundamental Idea, Whewell sketched how he thought that Kant's problem of bridging the gap between the metaphysical foundations of natural science and physics could be solved. The intermediary concepts that Kant was trying to establish correspond to the Axioms in Whewell's philosophy.

If the above analysis is correct, then we have shown that Whewell's account of the Idea of Cause (and by extension, his doctrine of Fundamental Ideas in general) grew out of his dissatisfaction with Kantian philosophy of science and its seeming inability to solve the bridging-problem. This analysis throws new light on the importance of Kantianism in Whewell's philosophy, for we have shown that Whewell took over and transformed Kant's idea of a priori principles as conditions for the establishment of proper knowledge about the world (without always clinging to Kant's exact differentiation between them) and that Whewell was trying to address a typical Kantian topic: namely, to show

${ }^{143}$ Ibid., 660. 
33

how scientific knowledge could be both empirical and necessary and how the gap between metaphysics and physics could be bridged.

\section{Bibliography}

Adickes, E. (1920). Kants Opus postumum, dargestellt und beurteilt. Berlin: Reuther \& Reichard.

Butts, R.E. (1965). Necessary Truths in Whewell's Theory of Science. In: American Philosophical Quarterly 2.3, 161-181.

Butts, R.E. (1994). Induction as Unification: Kant, Whewell, and Recent Developments. In: Kant and Contemporary Epistemology. Ed. by P. Parrini, Dordrecht: Kluwer.

Carrier, M. (2001). Kant's Mechanical Determination of Matter in the Metaphysical Foundations of Natural Science. In: Kant and the Sciences. Ed. by E. Watkins. Oxford: Oxford University Press.

Caygill, H. (2005). The Force of Kant's Opus postumum, Kepler and Newton on the xith fascile. In: Angelaki, Journal of the Theoretical Humanities 10.1, 33-42.

Ducheyne S. (to appear). Whewell, Necessity and the Inductive Sciences. In: South African Journal of Philosophy.

Fisch, M. (1985). Necessary and Contingent Truth in William Whewell's Antithetical Theory of Knowledge. In: Studies in History and Philosophy of Science 16.4, 275-314.

Fisch, M. (1991). William Whewell, Philosopher of Science. Oxford: Clarendon Press.

Förster, E. (2000). Kant's Final Synthesis: An Essay on the Opus postumum. Cambridge, Mass.: Harvard University Press.

Förster, E. (1987). Is there "A Gap" in Kant's Critical System?, Journal of the History of Philosophy 25.4, 533-555.

Friedman, M. (1992). Kant and the Exact Sciences, Cambridge, Mass.: Harvard University Press.

Friedman, M. (2003a), Transcendental Philosophy and Mathematical Physics, Studies in History and Philosophy of Science 34.1, 29-43.

Friedman, M. (2003b). Eckart Förster and Kant's Opus Postumum. In: Inquiry - An Interdisciplinary journal of Philosophy 46.2, 215-227.

Hoppe, H.G. (1969). Kants Theorie der Physik, Eine Untersuchung über das Opus postumum von Kant. Frankfurt: Klostermann.

Mathieu, V. (1989). Kants Opus Postumum. Frankfurt: Klostermann. 
34

Rueger, A. (1995). Brain Water, the Ether and the Art of Constructing Systems. In: Kant Studien 86.1, 26-40.

Snyder, L.J. (2006). Reforming Philosophy, A Victorian Debate on Science and Society. Chicago: University of Chicago Press.

Tuschling, B. (1971). Metaphysische und Transzendentale Dynamik in Kants Opus postumum. Berlin: De Gruyter.

Watkins, E. (2001). Kant's Justification of the Laws of Mechanics. In: Kant and the Sciences. Ed. by E. Watkins, Oxford: Oxford University Press.

Whewell, W. (2001[1840]). The Philosophy of the Inductive Sciences, Founded Upon Their History. In: Collected Works of William Whewell, Ed. R. Yeo. Bristol: Thoemmes Press, IV-V.

Whewell, W. (2001[1858]). Novum Organum Renovatum. In: Collected Works of William Whewell, Ed. R. Yeo. Bristol: Thoemmes Press, VI.

Whewell, W. (2001 [1860]). On the Philosophy of Discovery. In: Collected Works of William Whewell, Ed. R. Yeo. Bristol: Thoemmes Press, VII.

Yeo, R. (1979). William Whewell, Natural Theology and the Philosophy of Science in Mid Nineteenth Century Britain. In: Annals of Science 36.5, 493-516. 